\section{Steps out of time}

Eric Ashby

Walkers. By Miles Jebb. Constable, London: 1986. Pp.202. £10.95.

Sixry years ago, devotees of the nonfiction book at bedtime were well supplied by a genre which is now rare: the essay. Contemporaries of Chesterton, Belloc and Aldous Huxley had plenty of entertainment awaiting them at the end of the day. Today there are very few competent practitioners in that style of writing. One can still enjoy the classical essayists Charles Lamb for the light-hearted, Emerson for the sober-minded, and Montaigne and Bacon - but who is writing in that style now?

Well, Miles Jebb for one. His book, Walkers, is in the tradition of the whimsical nineteenth-century essayists. In eleven brief chapters Jebb writes about the various kinds of people who walk or have walked: pilgrims, athletes, intellectuals, tramps, ramblers... I'll not disclose the whole list. The book is a compilation of anecdotes and episodes from history and fiction, told with the comfortable informality of after-dinner conversation, by a man with a well-stocked mind.

If you start to delve into the literature

This is a great book, and an exciting book... readable, worth reading and enlightening.

Sir Karl Popper

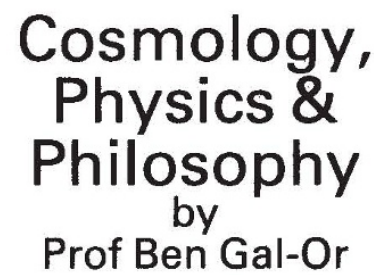

"a master piece... any good library must have a copy of this classical work."

Ind. J. Phys.

“... a tour de force... will be widely read and appreciated... a magnificent and sustained piece of work!"

\section{Sir Alen Cottrell}

... remarkable... challenging... Am. J.Phys.

\section{2nd Printing}

Springer-Verlag

175 5th Ave., N.Y., 10010 about walking, it is surprising what turns up. Each of Jebb's eleven kinds of walker finds himself heir to certain conventions. The value of a pilgrimage may be enhanced by discomfort: "The Countess of Clare threw away her shoes as she started on a pilgrimage". Athlete-walkers are out to break records: Sean Maguire, who "in 1978 walked the 7327 miles from Yukon to Florida in three hundred and seven days"; and Sebastian Snow, who reckoned he had taken some $11,745,000$ paces in his walk from the tip of South America to Panama City with a $60 \mathrm{lb}$ pack on his back. Intellectual walkers are the most articulate (witness Hilaire Belloc's Path to Rome) and they often philosophize as they walk. Or they boast of a kind of muscular intellectualism: thus Leslie Stephen, when at Cambridge, walked to London (over 50 miles) in 12 hours to attend a dinner of the Alpine Club.

Tramps fall into two categories: those who walk because they have nowhere else to go, and those who "walk away from convention". The former are inarticulate (though the poet W.H. Davies was an exception); the latter, such as Stevenson and Maxim Gorky, often become tramps in order to collect material for writing. Ramblers not only ramble; they combine to form pressure groups to lobby for conservation, and they sometimes flock together in group walking. They are somewhat querulous, having been driven off the roads by traffic, but we are indebted to them for their lobbying: in the United States, the Sierra Club has a fine record in defending the wilderness, and in Britain the Ramblers' Association has preserved many footpaths that would otherwise have been obliterated by farmers.

If you like erudite and genial conversation about themes such as these, this is a bedtime book to savour.

Lord Ashby is a Fellow of Clare College, Cam bridge CB2 1TL, UK.

\section{Thought of biology}

\section{P.T. Saunders}

Biophilosophy: Analytic and Holistic Perspectives. By Rolf Sattler. SpringerVerlag: 1986. Pp.284. Pbk DM66

ROLF Sattler is a biologist who believes that it is important to understand the fundamental presuppositions of biology and how they influence research and even our view of life itself. In Biophilosophy he sets out to introduce other biologists to these ideas.

I am in full sympathy with Sattler's aim, and he has gone some way towards achieving it. But there are reservations. The book seems to be intended as both an introductory text and a monograph, and rather falls between the two stools. Far too much material has been crammed into a text that also has to include elementary expositions of basic ideas. As a result, some explanations are marred by what are, for the beginner, digressions. At other times, Sattler rushes along at great speed; he deals with the issue of free will in just over a page. Many terms and ideas are mentioned so flcetingly that the reader not only is left uninformed about them but will not even be able to grasp how they are relevant to the discussion.

Often Sattler does no more than mention that a certain idea has been put forward and give some references. For example, he considers that the idea of species as individuals rather than classes leads to the scientific view of unity or oneness to which he devotes the last chapter. Yet he says very little in support of the idea, beyond mentioning the common gene pool and providing some references to "a critical appraisal" of the concept. It would have been better to spend more time on those questions that he considers to be most important, and to compensate by omitting some other material altogether.

Biophilosophy, then, is not a satisfying book. The author seems to have tried to get down in print everything he has thought about, from plant morphology to Zen Buddhism. Further, aspects of the selection of material and the relative emphasis given to different topics mean that he has not fully assimilated all that he has learned into a coherent whole. On the other hand, if Biophilosophy loses by not having been written by a professional philosopher, it also gains from having been written by a working scientist to whom these ideas matter, and who sees many of the issues from the same point of view as his readers.

Far too few biologists are aware of the philosophical issues that underlie and influence what they do. Moreover, because so much of the philosophy of science is concerned with physics, not biology, it is not readily accessible to them. Biologists who read this book will become acquainted with many important questions, and, what is more, will have them explained in familiar terms - there are not many introductions to the philosophy of science that illustrate the basic concepts through plant morphology, instead of quantum mechanics. I even approve of reminding the reader that plant morphology and Zen Buddhism are both worth thinking about, and not necessarily in separate intellectual compartments. I only wish Sattler had tightened the whole thing up a bit.

P.T. Saunders is in the Department of Mathe matics, King's College London (KQC), Strand, London WC2R $2 L S$, UK. 